\title{
Are complicated monochorionic twins more susceptible to indomethacin-induced fetal ductal constriction? Two cases of laser surgery for Twin-Twin Transfusion syndrome
} Komplike monokoryonik gebelikler indometazinin neden olduğu fetal duktus arteriozus konstriksiyonuna daha mı duyarlıdır? İkizden İkize Transfüzyon sendromu nedeniyle lazer cerrahisi yapilan iki olgu

\author{
(1) Hakan Erenel, (1) Mehmet Fatih Karslı, (1) Sevim Özge Korkmaz, (1) Cihat Şen
}

İstanbul University Cerrahpaşa Faculty of Medicine, Department of Obstetrics and Gynecology, Division of Perinatal Medicine, İstanbul, Turkey

\begin{abstract}
Indomethacin is a commonly used medication against preterm delivery. Several reports of fetal ductal constriction have been described after indomethacin use in the literature; however, there are no previously documented reports describing an association between Twin-Twin Transfusion syndrome and a constrictor effect of indomethacin on the ductus arteriosus. Two patients were referred to our department for Twin-Twin Transfusion syndrome and each underwent placental laser surgery. Constriction of the ductus arteriosus occurred as early as 20 and 24 weeks' gestation following maternal use of indomethacin after laser surgery. Spontaneous amelioration was observed after discontinuation of the drug. The constrictor effect of indomethacin on the ductus arteriosus can be observed even after a single dose and as early as 20 weeks of gestation in complicated monochorionic twin pregnancies. We emphasize meticulous use of indomethacin in complicated monochorionic twin pregnancies because the constrictive effect seems to be independent of gestational age.
\end{abstract}

Keywords: Constriction, ductus arteriosus, indomethacin, preterm labor, Twin-Twin Transfusion syndrome

$\ddot{O} z$

İndometazin preterm eylem durumunda sıklıkla kullanılan bir ilaçtır. Literatürde indometazin ve duktus arteriozus konstriksiyonu ile ilgili olgular rapor edilmişse de ikizden ikize transfüzyon sendromu ile ilişkisini vurgulayan bir çalışma yoktur. Hastanemize İkizden İkize Transfüzyon sendromu tanısı ile iki olgu refere edilmiştir ve bu olgulara plasental lazer cerrahisi uygulanmıștır. Cerrahi sonrası uterin kontraksiyonları engellemek amacıyla indometazin tedavisi verilmiştir ve 20 ve 24. gebelik haftasında olan bu olgularda duktus konstriksiyonu gelişmiştir. Tedavi kesildikten sonra klinik tablo kendiliğinden düzelmiştir. Komplike olan monokoryonik ikiz gebeliklerde indometazinin duktus arteriozus üzerindeki konstriktor etkisi tek doz sonrası bile 20. gebelik haftası gibi erken bir gebelik haftasında gözlenebilir. İndometazinin duktus üzerine olan etkisi gebelik haftasından bağımsız olduğundan komplike monokoryonik ikiz gebeliklerde indometazin dikkatli kullanılmalıdır.

Anahtar Kelimeler: Konstriksiyon, duktus arteriozus, indometazin, preterm doğum, İkizden İkize Tansfüzyon sendromu

Address for Correspondence/Yazıșma Adresi: Hakan Erenel, MD,

İstanbul University Cerrahpaşa Faculty of Medicine, Department of Obstetrics and Gynecology, Division of Perinatal Medicine, İstanbul, Turkey

Phone: +90 5063092995 E-mail: hakanerenel@yahoo.com ORCID ID: orcid.org/0000-0001-7583-5385

Received/Geliș Tarihi: 19.03.2018 Accepted/Kabul Tarihi: 05.06.2018

${ }^{\oplus}$ Copyright 2018 by Turkish Society of Obstetrics and Gynecology

Turkish Journal of Obstetrics and Gynecology published by Galenos Publishing House. 


\section{Introduction}

Monochorionic (MC) twins are a subtype of monozygotic (MZ) pregnancies and are seen in $0.3 \%$ of all pregnancies. MC diamniotic pregnancies are the most common subtype of $\mathrm{MZ}$ pregnancies and account for $70-75 \%$ of all $\mathrm{MZ}$ pregnancies ${ }^{(1)}$. Twin-Twin Transfusion syndrome (TTTS) is a complication of MC twin pregnancies and foetoscopic laser photocoagulation is one of the treatment options; however, laser surgery increases the risk of abortion/preterm delivery. Indomethacin is a commonly used medication against preterm delivery. Several reports of fetal ductal constriction have been described after indomethacin use in the literature. Here, we present two cases of antenatally diagnosed foetal ductal constriction in the donor co-twin after indomethacin use.

\section{Case Reports}

\section{Case 1}

A 24-year-old gravida-3-para-2 at 24 weeks' gestation was referred to our department for TTTS. Her physical and gynecologic examinations were usual. Fetal examination revealed a diamniotic MC twin pregnancy. The recipient twin was diagnosed as having polyhydramnios and the donor twin had oligohydramnios. The diagnosis of stage 3 TTTS was made on the basis of Quintero Staging system. A negative ductus venosus A-wave was observed in the recipient twin. The deepest vertical pocket was $140 \mathrm{~mm}$ for the recipient and $5 \mathrm{~mm}$ for the donor twin. The complications and prognosis of TTTS and risks of placental laser surgery were discussed with the family and the patient opted for placental laser surgery. The patient underwent placental laser surgery under local anaesthesia in operating room. On the day of the operation, $100 \mathrm{mg}$ indomethacin was administered due to regular uterine contractions as rectal suppository once a day. Indomethacin administration was continued until postoperative day 2 and the contractions disappeared. On postoperative day 3, an ultrasound examination revealed pleural effusion, ascites, increased nuchal thickness, oligohydramnios, tricuspid regurgitation, and negative ductus venosus A-wave in the donor twin and normal Doppler findings in the recipient twin. A detailed examination of the ductus arteriosus showed ductal narrowing with a transverse diameter of $1.49 \mathrm{~mm}$ $\left(<5^{\text {th }} \text { percentile) (Figure } 1\right)^{(2)}$. There was no turbulent flow or aliasing in the ductus arteriosus region and systolic and diastolic velocities were 69 and $6 \mathrm{~cm} / \mathrm{s}$, respectively. Although Doppler criteria of ductal constriction were not observed, hydrops was prominent. The indomethacin treatment was stopped. The direction of ductus venosus flow turned to positive on the next day and further examination revealed a $50 \%$ increase in the transverse diameter of the ductus arteriosus, and the ductal arch returned to its normal shape (Figure 2). The tricuspid regurgitation and ascites, and pleural effusion disappeared completely on postoperative

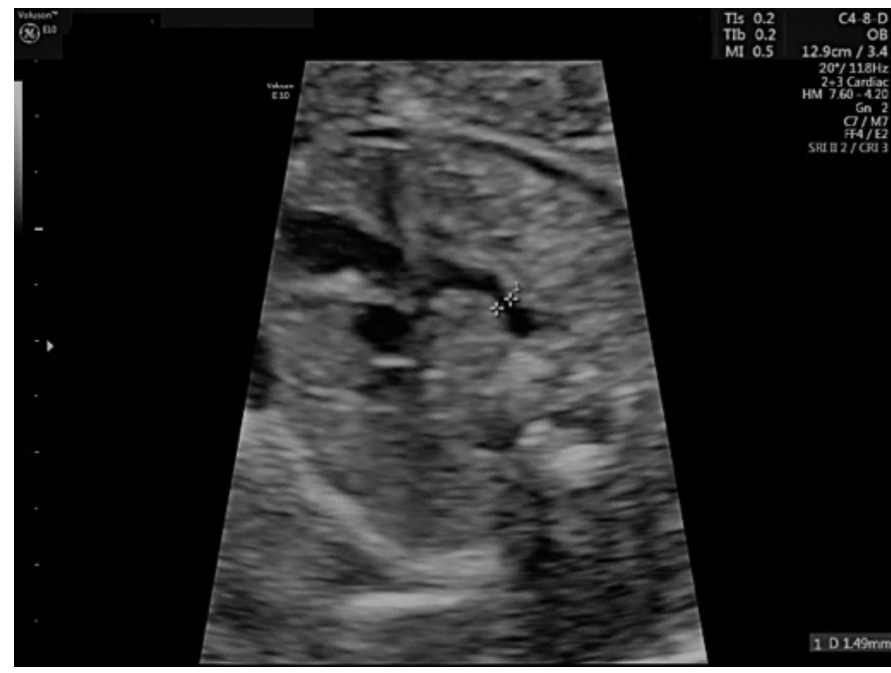

Figure 1. Narrowing in the ductus arteriosus (Case 1)

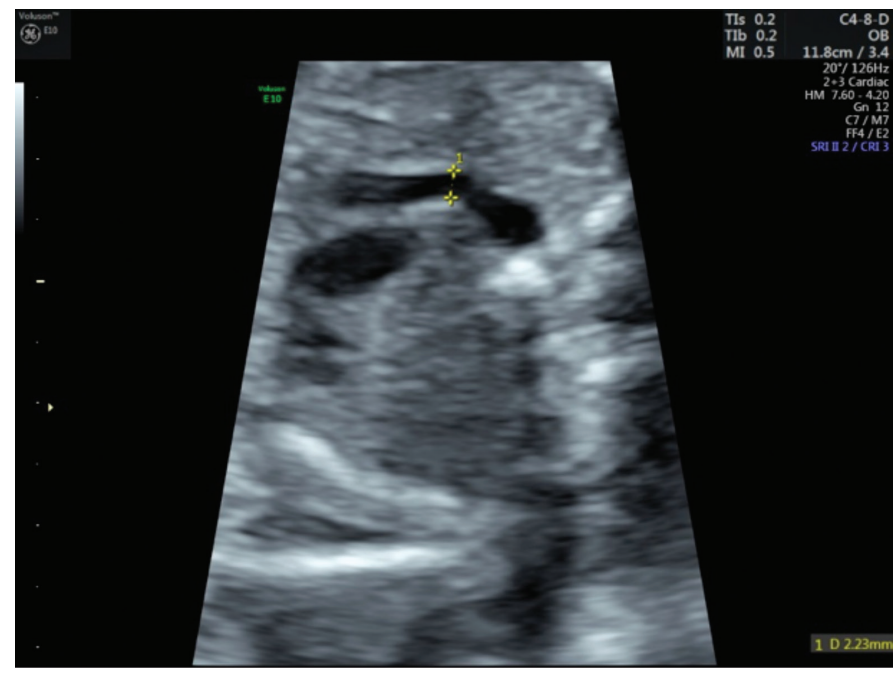

Figure 2. Transverse diameter of ductus arteriosus after resolution of the constriction (Case 1)

days 5 and day 7 , respectively. The patient was discharged on tenth day postoperatively. Her antenatal visits were uneventful until delivery. The patient underwent a cesarean section for breech-vertex presentation at 35 weeks' gestation. Male infants weighing 2200 and $2100 \mathrm{~g}$ were delivered.

\section{Case 2}

A 25-year-old gravida-2-para-1 at 20 weeks' gestation was referred to our department for TTTs. The patient reported abdominal bloating. The diagnosis of TTTs stage 2 was made on the basis of Quintero staging. The deepest vertical pocket was $154 \mathrm{~mm}$ for the recipient and $10 \mathrm{~mm}$ for the donor twin. The estimated foetal weight (EFW) was less than $10^{\text {th }}$ centile for donor twin. Placental laser surgery was performed after preoperative counselling. Postoperatively, a single-dose 100 $\mathrm{mg}$ indomethacin suppository was inserted into the rectum to prevent uterine contractions. On the next day (postoperative 
day 1), constriction of the ductus arteriosus and tricuspid regurgitation were observed in the donor twin. There was a marked ductal narrowing (Figure 3). The peak systolic velocity was $149 \mathrm{~cm} / \mathrm{s}$ (Figure 4). On postoperative day 3, the transverse diameter of the ductus arteriosus and peak systolic velocity returned to normal (Figure 5). On postoperative day 5 , the tricuspid regurgitation had disappeared and the patient was discharged. On the next day, the patient was admitted to the hospital due to regular contractions and cervical opening and she delivered at 21 weeks and 3 days' gestation.

\section{Discussion}

Preterm delivery is a major cause of perinatal morbidity and mortality. Indomethacin is relatively old and the most commonly used prostaglandin synthetase inhibitor, it has been used in preterm delivery since the 1970s. Maternal use of indomethacin is the most common cause of foetal ductus arteriosus constriction; however, idiopathic constriction of the fetal ductus arteriosus has also been described in the

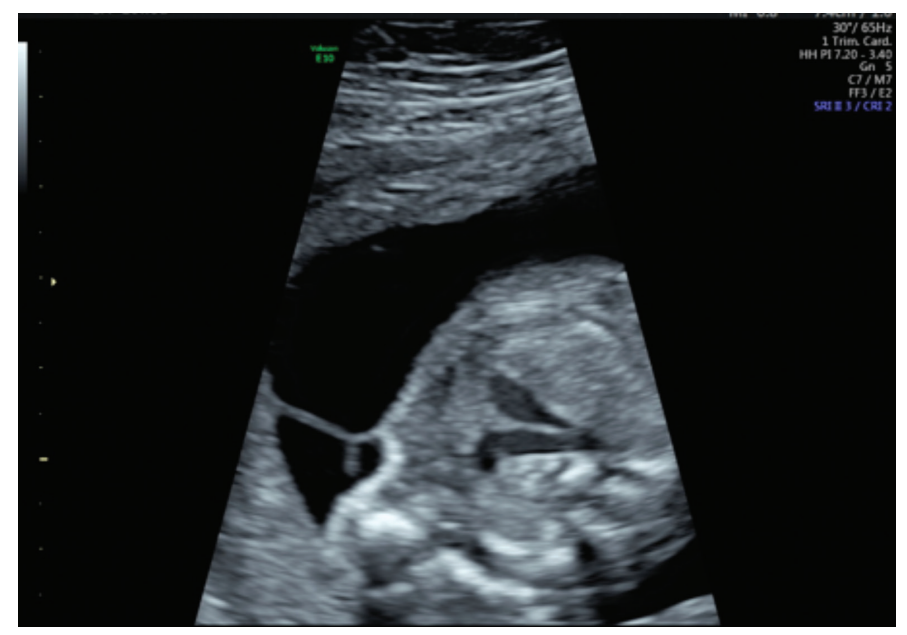

Figure 3. Narrowing in the ductus arteriosus (Case 2)

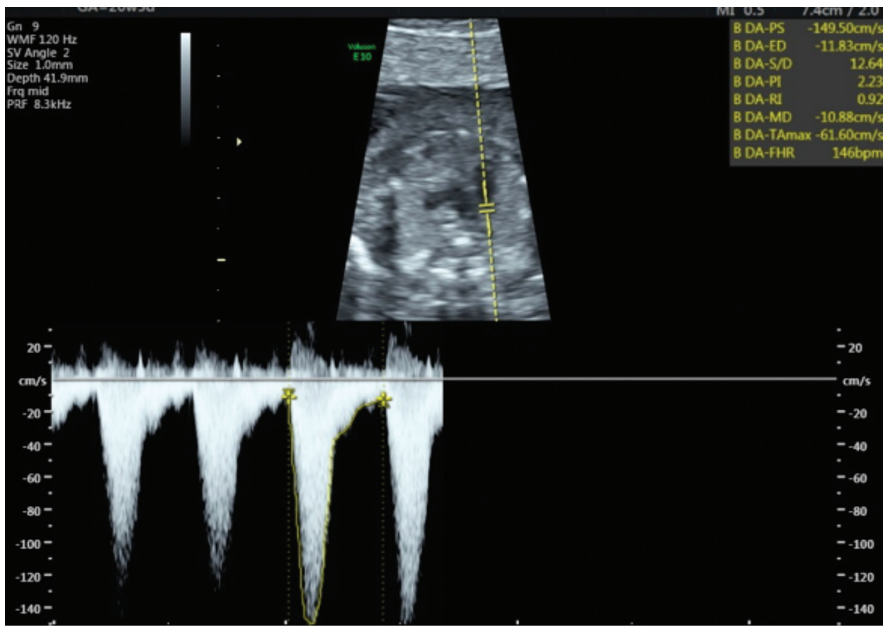

Figure 4. Elevated peak systolic velocity in the ductus arteriosus (Case 2) literature $^{(3)}$. The diagnostic criteria of ductal constriction are as follows: a) presence of turbulent flow with a continuous pattern in the ductus arteriosus region (systolic and diastolic) in colour Doppler; b) systolic velocity $\geq 1.4 \mathrm{~m} / \mathrm{s}$; and c) diastolic velocity $\geq 0.3 \mathrm{~m} / \mathrm{s}^{(4)}$. To the best of our knowledge, this is the first report of prenatal diagnosis of constriction of ductus arteriosus in as early as 20 and 24 weeks' gestation following maternal use of indomethacin in complicated MC twins after laser surgery. Prostaglandin inhibitors such as indomethacin are tocolytic agents, which act by decreasing prostaglandin activity in the uterine myometrium. However, decreased prostaglandin synthesis in the foetal circulation may have adverse effects on the ductus arteriosus because prostaglandins mainstay ductal patency. Fetal ductal constriction is a distinct entity caused by different drugs (non-steroidal anti-inflammatory drugs, fluoxetine or abuse of some drugs); however, idiopathic/spontaneous constriction of foetal ductus arteriosus has also been described in the literature ${ }^{(5)}$. Tricuspid regurgitation, right ventricular dilatation, oligohydramnios, ascites, hydrops, and increased nuchal translucency are common foetal findings in such cases. A case series reported 45 cases of fetal ductus arteriosus constriction and closure, including 8 idiopathic forms. The most common finding of ductal constriction was tricuspid regurgitation, present in $86.6 \%$ of patients ${ }^{(5)}$. Although indomethacin was administered as a single dose at 20 weeks' gestation and once a day for 2 days at 24 week's gestation, our cases presented with constriction of the ductus arteriosus. As we know from previous reports, constriction of the ductus arteriosus is not dependent on serum indomethacin levels ${ }^{(6)}$. Vermillion et al. ${ }^{(7)}$ analysed the effect of indomethacin tocolysis on fetal ductus arteriosus constriction of 72 fetuses and reported that the greatest incidence of ductal constriction occurred at 31 weeks' gestation. The earliest gestational age for ductal constriction was reported at 24.7

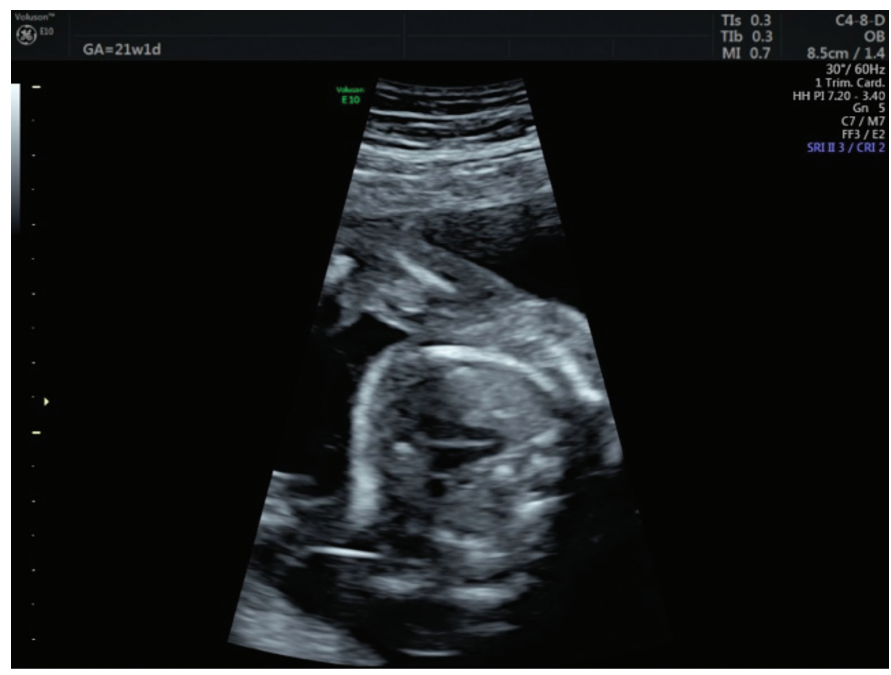

Figure 5. Transverse diameter of the ductus arteriosus after resolution of the constriction (Case 2) 
weeks' gestation ${ }^{(7)}$. Therefore, it could be argued that the ductal effect of indomethacin is unpredictable for the foetus at any gestational age. Complete and irreversible closure of the ductus arteriosus can be observed even after a single dose of indomethacin, whereas ductus arteriosus can remain unaffected despite repeated doses. In our cases, constriction of the ductus arteriosus was seen only in the donor twin. In our opinion, this effect was observed only in the donor twins because of the relatively hypoxic conditions of donor foetuses. A selective constrictive effect of indomethacin on MC twins has been shown previously in some pathologically proven reports ${ }^{(8)}$. Furthermore, indomethacin can decrease fetal urine output and lead to deterioration in amniotic fluid levels in the donor foetus. Thus, it seems reasonable to use tocolytics other than indomethacin in TTTS. Just a few cases of hydrops and constriction of ductus arteriosus following indomethacin use have been described in the literature and none presented as early as 24 weeks' gestation. As in our case, hydrops resolved after discontinuation of indomethacin ${ }^{(9)}$. Indomethacin use is associated with a risk of constriction of the ductus arteriosus at any gestational age; however, this condition and its effects can present in the absence of Doppler criteria. In case 1, the absence of Doppler criteria can be explained by the relatively early gestational age and severe tricuspid regurgitation. Tricuspid regurgitation allows the right ventricle to empty and may prevent turbulent flow in the ductus arteriosus. In conclusion, these are the first reported cases of foetal ductal constriction in complicated MC twin pregnancy presenting as early as 20 weeks' of gestation. Therefore, we emphasize meticulous use of indomethacin in complicated MC twin pregnancies because the constrictive effect seems to be independent of gestational age. In the event of indomethacin use, Doppler indices of the ductus arteriosus should be closely monitored.

Ethics

Informed Consent: Was taken.

Peer-review: Externally peer-reviewed.

\section{Authorship Contributions}

Surgical and Medical Practices: C.Ş., H.E., Concept: C.Ş., M.F.K., Design: C.S., H.E., M.F.K., Data Collection or Processing: M.F.K., S.Ö.K., Analysis or Interpretation: H.E., S.Ö.K., Literature Search: M.F.K., S.Ö.K., Writing: H.E., C.Ş.

Conflict of Interest: No conflict of interest was declared by the authors.

Financial Disclosure: The authors declared that this study received no financial support.

\section{References}

1. Hall JG. Twinning. Lancet 2003;362:735-43.

2. Mielke G, Benda N. Reference ranges for two-dimensional echocardiographic examination of the fetal ductus arteriosus. Ultrasound Obstet Gynecol 2000;15:219-25.

3. Enzensberger C, Wenhard J, Weichert J, Kawecki A, Degenhardt J, Vogel M, et al. Idiopathic constriction of the fetal ductus arteriosus: three cases and review of the literature. J Ultrasound Med 2012;31:1285-91.

4. Huhta JC, Moise KJ, Fisher DJ, Sharif DS, Wasserstrum N, Martin C. Detection and quantitation of constriction of the fetal ductus arteriosus by Doppler echocardiography. Circulation 1987;75:406-12.

5. Lopes LM, Carrilho MC, Francisco RP, Lopes MA, Krebs VL, Zugaib M. Fetal ductus arteriosus constriction and closure: analysis of the causes and perinatal outcome related to 45 consecutive cases. J Matern Fetal Neonatal Med 2016;29:638-45.

6. Van den Veyver IB, Moise KJ Jr, Ou CN, Carpenter RJ Jr. The effect of gestational age and fetal indomethacin levels on the incidence of constriction of the fetal ductus arteriosus. Obstet Gynecol 1993;82:500-3.

7. Vermillion ST, Scardo JA, Lashus AG, Wiles HB. The effect of indomethacin tocolysis on fetal ductus arteriosus constriction with advancing gestational age. Am J Obstet Gynecol 1997;177:256-9.

8. Shehata BM, Bare JB, Denton TD, Habib MN, Black JO. Premature closure of the ductus arteriosus: variable response among monozygotic twins after in utero exposure to indomethacin. Fetal Pediatr Pathol 2006;25:151-7.

9. Pratt L, Digiosia J, Swenson JN, Trampe B, Martin CB Jr. Reversible fetal hydrops associated with indomethacin use. Obstet Gynecol 1997;90:676-8. 